\title{
Relationship Between Spot Prices and Futures Prices: Evidence From Karachi Stock Exchange
}

\author{
Muhammad Asif Ali \\ Lecturer, Department of Management Sciences \\ University of Swabi, Swabi, KPK. \\ Dr. Arshad Hassan \\ Dean Faculty of Management, and Social Sciences \\ Capital University of Science and Technology, Islamabad \\ Arshad.hasan@gamil.com \\ Dr. Naveed Hussain Shah, \\ Assistant Professor, Department of Management Sciences, \\ University of Swabi, Swabi, KPK. \\ dr.naveedshah@uoswabi.edu.pk
}

\begin{abstract}
This study investigates the relationship between futures prices and their underlying spot prices of the stocks trading on Pakistan stock market. Data on the monthly closing prices of future contracts and their underlying stocks of 30 companies for the period January 2004 to June 2014 have been taken for analysis. Descriptive statistics, Augmented Dicky Fuller test for unit root testing, Johnson Co-integration test, Granger causality test and Vector Error Correction Model are used. The results confirms significant long term relationship between futures prices and the associated Spot prices in case of 26 companies. The report of Granger causality test indicates that a Bi-directional causality lack to exist in case of each security, VECM shows that Spot prices for current month are effected by previous month prices in case of 7 companies, while futures prices of current month are affected by previous month prices in case of 4 companies. VECM illustrates that the volatility shocks in spot market are less effected by futures market, however the volatility shocks in corresponding futures market were strongly and significantly affected by spot market volatility.
\end{abstract}

Key words: KSE, VECM, S\&P 500, GARCH, FTSE

\section{Introduction}

Future contracts are made on assets, with a monetary value. Currently commodity futures, currency futures, interest rate futures and equity futures are trading on a futures exchange and in countries where formal futures exchange lack to exist then a stock exchange is there to perform the role of a futures exchange (Brooks et al, 2001). A future contract is the standardized contract between two parties to buy or sell a particular asset today, to deliver at a particular date in time, at a certains agreed rate, in future, (Jamal \& Faraz, 2013; Sharma, 2011 and Brooks et al, 2001).

In Pakistan the future contracts which are traded in Karachi stock exchange are equity futures (Nasir \& Jamal, 2013). Many researchers like (Karathanassis and Sogiakas, 2007; Jackline and Deo, 2011; Jamal and Faraz, 2013; and Hamidullah and Ataullah, 2013) had conducted studies to 
find relationship between prices of these specific future contracts and of the underlying assets on which these contracts are made. All these researchers found the existence of specific association between futures and their underlying assets. Some people found that there exists a lead lag relationship between the two markets. This lead-lag relationship exists because of the fact that financial markets are not efficient (Floros \& Vougas, 2007; Ullah \& Shah, 2013 and Jamal \& Faraz, 2013). Efficiency here implies to efficient market theory (Eugene Fama, 1960). If efficiency exist then both of the market will respond quickly and simultaneously, with no lead-lag time, and investors would be able to take a specific position in either market (Kawaller \& Koch, 1987 and Stoll \& Whaley, 1990).

Fully and strong form efficiency does not exist in any market. It is very difficult to attain robusttype of market efficiency in a marketplace, no matter how much it is developed or structured technologically and infrastructural. Therefore, possibility exist that one market, on receiving information, as both are dependent on one another, may respond quickly and the other will follow (Kapil and Bajaj, 2012). Findings of various studies reveals that future markets are more efficient to information and respond quickly while the spot market follow that change in futures market (Frino et al. 2000; Thenmozhi, 2002; Mukherjee and Mishra, 2006; Floros and Vougas 2008; Jackline \& Malabika). It is argued that future markets also play important role in price discovery (Thiessen, 2012). It is due to the fact that Future market has low transaction costs, low margin requirements, high liquidity, leverage benefits, and less restrictions on trading as compare to stock market, (Telser 1981; \& Figlewski 1981).

In the context of Pakistani stock market there is no clear consensus on the relationship between spot market and futures market, and the results are debatable. There is very little evidence about the existence of long term, short term and lead lag relationship, on the basis of which we can give some clear recommendation about the behavior of the futures market. Investors and traders has a greater concern with futures market and takes on coincident positions by moving from spot to futures and from futures to spot market due tothe market instability and arbitrage opportunity open to them to outperform the market. This problem motivates the body of research to explore that relationship.

\section{Literature Review}

Turnovsky (1983), Kawaller et al. (1987), Chan (1992), Tang et al. (1992), Alphonse (2000), Brokes, Rew and Ritson (2001), Bologna and Cavalo (2002), Zhong et al. (2003), Hung and So (2003), Floros and Vougas (2007), Sariannidis and Drimbetas (2008), Madarrasy and Fichmar (2009), Beer (2009), Debaish (2009), Thiessen (2012), Hamidullah and Ataullah (2013), found that it is futures market that play the leading role in responding to the receipt of information and spot market follow that behavior. Safiullah (2006), Lin et al. (2002), Galloway and Miller (1997), Mallikarjunappa and Afsal (2010), Judge and Reancharoen (2014), found that spot market leads the futures market in determining prices and incorporating volatility.

Kavussanus and Visvikies (2008), Jackline and Deo (2011), Choudhry and Bajaj (2012), found Bi-directional causality between futures and spot market.

Karathanasis and Sogiakas (2010), Jithendranathan (2010), found no relationship between respective futures and spot markets.

\section{Data Description and Methodology}

The data used for analysis is secondary in nature. Monthly closing prices for Single stocks futures were taken from the KSE website and that of individual stocks was taken from Business recorder 
website. Data on the monthly closing prices of Futures contracts and their underlying stocks for 30 securities starting from Jan 1, 2004 to June 30, 2014 is used.

After getting data, we calculated monthly returns for Spot prices as well as futures prices by taking the natural $\log$ of 2 months consecutively. Log is used here for smoothening the linear series of the data. Formula used for calculating those monthly returns is given as under.

$\mathbf{R}_{\mathbf{t}}=\mathbf{L}_{\mathbf{n}}\left(\frac{\mathbf{P}_{\mathrm{t}}}{\mathbf{P}_{\mathrm{t}-1}}\right)$

Where Rt is used here to represent return for month " $t$ "; while Pt and Pt-1 are closing values on monthly basis for period " $\mathrm{t}$ " and "t-1" respectively.

The data is analyzed through following techniques.

I. Descriptive Statistics

II. Augmented Dicky Fuller Test

III. Granger Causality Test

IV. Johnson Co-integration test

V. Vector Error Correction Model

I. Descriptive Statistics

For assessing the distributive properties of both the time series various descriptive statistics are used. Descriptive statistics used are Mean, Standard deviations,Median, Minimum, Maximum values andSkewness.

\section{Unit root test}

After examining descriptive statistics for both the time series, the unit root testing is used to test the Stationarity of the data. Stationarity is the feature of the data in which mean of the data is zero and its variance is constant. Augmented Dicky fuller test (ADF) is used to check the stationarity of a large sample, it is applied here to determine whether data has a unit root or not (Jamal and Faraz, 2013). There was a unit root existing when ADF was applied at Level. However, both the series for each company are found Stationary when ADF was applied at $1^{\text {st }}$ difference. This implies that the time series data is integrated to the order of one or I (1). The equations used for Dicky fuller test are given as under, Pt represent the log series for both the futures and spot pries.

$\Delta \mathbf{P}_{\mathrm{t}}=\mathbf{y P}_{\mathrm{t}-\mathbf{1}}+\boldsymbol{\epsilon}_{\mathrm{t}}-\mathrm{-}_{-}$

This equation represents DF (Dicky Fuller) test for price series having no drift and trend terms.

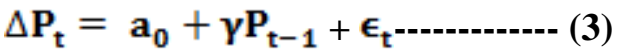

This equation represents DF test for price series having drift only.

$\Delta P_{t}=a_{0}+\gamma P_{t-1}+a_{2} t+\epsilon_{t^{-}---(4)}$

This equation represents DF test for price series having both drift and trend terms.

\section{Johnson Co-integration test}

It is suggested that if data is Stationary to order of (I), then Co-integration model is the preferred tool to model this type of long term equilibrium relationship. Johnson Co-integration test is applied to determine the presence of long run stable equilibrium association between return series of spot prices and futures prices (Kavussanos et al, 2007). For that purpose, the natural log of the two price series is taken to calculate the linear return series, and then Johnson Co-integration test is applied.

The equation used for Co-integration model is given as under.

\section{$\mathrm{SP}_{\mathrm{it}}=\alpha_{0 \mathrm{i}}+\alpha_{1} \mathrm{FP}_{\mathrm{it}}+\epsilon_{\mathrm{it}}$}

This equation represents Co-integration model for Spot price series. 
$\mathrm{FP}_{\mathrm{it}}=\boldsymbol{\beta}_{0 \mathrm{i}}+\boldsymbol{\beta}_{1} \mathrm{SP}_{\mathrm{it}}+\epsilon_{\mathrm{it}}-\cdots$

This equation represents Co-integration model for Futures price series.

Where SP and FP denotes Spot prices and Futures prices respectively, $\alpha$ o and $\beta$ o are constant, whereas $\varepsilon$ represent the Error term.

\section{Granger causality test}

Granger causality is a statistical approach which is being applied for inferring the lead and lag relationship between two or more than two time series (Hamidullah and Ataullah, 2013).

The equation used for VAR (Vector Autoregressive) Model is given as under.

For RF causing RS

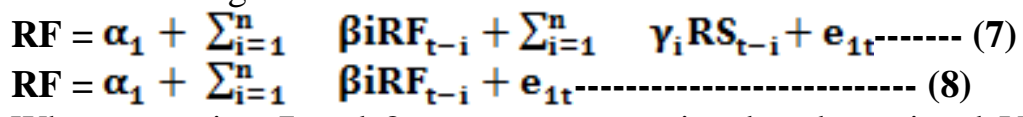

Where equation 7 and 8 represent unrestricted and restricted VAR model for RF causing RS respectively. RF mean return series for futures, while RS means return series for spot prices.

For RS causing RF

$\mathbf{R S}=\alpha_{2}+\sum_{\mathrm{i}=1}^{\mathrm{n}} \quad \boldsymbol{\beta i R S}_{\mathrm{t}-\mathrm{i}}+\sum_{\mathrm{i}=1}^{\mathrm{n}} \quad \mathbf{Y}_{\mathrm{i}} \mathbf{R F}_{\mathrm{t}-\mathrm{i}}+\mathbf{e}_{2 \mathrm{t}}-\cdots-\mathbf{-}^{-(9)}$

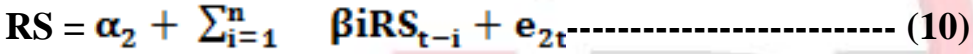

Where equation 9 and 10 represent unrestricted and restricted VAR model for RF causing RS respectively.

If one variable causes the other without being the opposite relationship in which the first is caused by the second, is termed as one-way causality. If both of the variables are causing one another, it is known as feedback or bi-directional causality between the two variables (Jamal and Faraz, 2013).

\section{Vector Error Correction Model}

After we found that the Log of Spot prices and Futures prices are Co-integrated and the order of integration is I (1), we checked the short tenureconnection between SP and FP through VECM. VECM reflects the adjustment of one variable over another variable (Kavussanos et al, 2007). The General equation used to express the VECM is given as under.

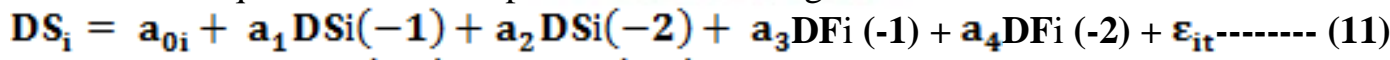

$\mathrm{DF}_{\mathrm{i}}=\boldsymbol{\beta}_{0 \mathrm{i}}+\boldsymbol{\beta}_{1} \mathrm{DFi}(-\mathbf{1})+\boldsymbol{\beta}_{2} \mathrm{DFi}(-\mathbf{2})+\boldsymbol{\beta}_{3} \mathrm{DSi}(-\mathbf{1})+\boldsymbol{\beta}_{4} \mathrm{DSi}(-2)+\boldsymbol{\varepsilon}_{\mathrm{it}}-\cdot-----$ (12) $^{-}$

Whereas DS and DF denotes Log of Spot prices and Futures price series respectively.

\section{Results and discussions}

The list of companies, the prices of which are being analyzed through above discussed tools is given in the appendix.

\section{Descriptive statistics}

The table given in the appendix shows the descriptive statistics for spot and futures prices. Different statistics used are Mean, Median, Skewness, Standard deviation, Maximum and Minimum. The mean value shows the average returns of the time series. As we have two series , descriptive statistics for both thefutures and spot returns are given. In case of spot market as well as futures market FCCL provides the smallest possible returns with a mean of -.035 and -.036 respectively. The table shows that LUCK gives maximum returns at a rate of .020 on its spot as well as its futures to its shareholders along with reasonable amount of risk. Standard deviation is the statistical tool for measuring the risk propensity of a series. KAPCO and HUBC are the safest securities in terms of risk with a standard deviation of .072 and .073 respectively for their futures 
series, and .084 and .077 for their Spot series. BOP stocks as well as futures has maximum risk of .177 for its Stocks and .162 for its futures, as compare to any other company, followed by DGKC which bear a standard deviation of .165 and .169 for its stocks and futures respectively. They provide comparatively small returns.

\section{Johnson Co-integration test}

Table given in appendix shows that 2 Co-integration equations exist between futures and spot returns series of the companies like ATRL, ENGRO, FCCL, FFBL, FFC, KAPCO, MCB, OGDCL, PIOC, POL, PPL, PSO and TELE. The companies which showed only one Cointegration equation are ACBL, BAHL, DGKC, DSFL, FABL, HUBC, ICI, LUCK, MLCF, NBP, NML, SNGP, and SSGC. Remaining companies lack to exist any Co-integration equation between its futures and spot eturn series. The securities showing some form of Co-integration reveals that spot and futures prices share common information in the long-run.

\section{Granger Causality Test}

The results of this test clearly shows that a bi-directional causality lack to exist in case of each security. However a unidirectional Granger causality exist in case of ACBL, ATRL, BOP, KAPCO, POL and SNGP in which the Null hypothesis is rejected that Rf does not Granger cause RS. It means that in case of above mentioned securities Futures market Granger causes spot market returns. On the other hand the null hypothesis that RS does not Granger causes RF was rejected at $95 \%$ confidence interval for DGKC, LUCK, ENGRO, HUBC, FFBL, NML and OGDCL. Granger causality results shows that in case of all remaining stocks neither Rs Granger causes Rf, nor Rf Granger causes Rs.

\section{Vector Error Correction Estimates}

We see that in case of ATRL, FCCL, HUBC, ICI, PSO and SSGC findings for both spot series and futures series are significant. It mean that there is short term relationship between spot prices and futures prices. In case of BAHL and NBP, spotseries effects futures significantly while ENGRO, FABL, FFBL, FFC, KAPCO, LUCK, MCB, NML, OGDCL, SNGP, TELE and UBL shows significance for their futures series. When checked for the first lag of spot seriesi.e. D(S (1)) it is founded that the first lag of spot series for FABL, FFC and PSO shows significant short term effect and relationship withboth spot series and futures series, securities like ATRL, FCCL, KAPCO and SNGP shows significant short term relationship for spot series and lag of spot series, while one security BOP shows short term relationship for its lag of spot series with spot series. In case of lag of futures seriesi.e.D (F (-1)), ATRL, BOP, FABL, PSO and SSGC shows significant short term relationship to both of its spot and futures series. While ACBL shows significance for spot series and ENGRO for futures series.

\section{Conclusion}

As we know that order of integration of the two time series were same, Johnson Co-integration test was applied to check for any long run connection. The maximum Eigen values statistics reported the presence of long run equilibrium connectionamong spot prices and futures prices in case of 26 companies. The results of maximum eigen values statistics were further confirmed by Trace statistics. The securities showing some form of Co-integration reveals that spot and futures prices shows same characteristics in the long-run.

The results of Granger causality clearly shows that a Bi-directional causality lack to exist in case of each security. However a Unidirectional Granger causality exist in case of ACBL, ATRL, BOP, KAPCO, POL. For ENGRO,DGKC,HUBC,FFBL, LUCK, NML and OGDCL no causality 
relationship exist. The outcomes of VECM demonstrates that in case of ATRL, FCCL, HUBC, ICI, PSO and SSGC both futuresand spot series are significant. It mean that there is short term relationship between spot prices and futures prices. In case of BAHL and NBP spot series effects futures significantly while ENGRO, FFC,FABL, KAPCO,FFBL, LUCK, NML, OGDCL, SNGP,MCB, TELE and UBL shows significance for their futures series.

VECM signifies that the volatility shocks in spot market are less effected by futures market but significantly effected by majority of its own shocks, however the volatility shocks in futures market were strongly and significantly effected by spot market volatility. It was also found that the volatility shocks in spot market is less effected by shocks occurring in futures market. The alternative hypothesis was found true for the futures market which was effected by spot market volatility shocks.

Summarizing the overall results it was found that there exist a long run equilibrium relationship between spot prices and their respective futures prices. This long run relationship between the two time series can help investors and hedgers in formulating proper and effective investment and hedging strategies. For efficient hedging the strong co-movement of the two time series is very important.

\section{References}

Figlewski, S. (1981). Futures trading and volatility in the GNMA market. The Journal of Finance, 36(2), 445-456.

Telser, L. G. (1981). Why there are organized futures markets. Journal of Law and Economics, 122.

Turnovsky, S. J. (1983). The determination of spot and futures prices with storable commodities. Econometrica: Journal of the Econometric Society, 1363-1387.

Kawaller, I. G., Koch, P. D., \& Koch, T. W. (1987). The temporal price relationship between S\&P 500 futures and the S\&P 500 index. The Journal of Finance, 42(5), 1309-1329.

Stoll, H. R., \& Whaley, R. E. (1990). The dynamics of stock index and stock index futures returns. Journal of Financial and Quantitative Analysis, 25(04), 441-468.

Tang, G. Y., Mak, S. C., \& Choi, D. F. (1992). The causal relationship between stock index futures and cash index prices in Hong Kong. Applied Financial Economics, 2(4), 187-190.

Chan, K. (1992). A further analysis of the lead-lag relationship between the cash market and stock index futures market. Review of financial studies, 5(1), 123-152.

Galloway, T. M., \& Miller, J. M. (1997). Index futures trading and stock return volatility: Evidence from the introduction of midcap 400 index futures. Financial Review, 32(4), 845-866.

Alphonse, P. (2000). Efficient price discovery in stock index cash and futures markets. Annales d'Economie ET de Statistique, 177-188.

Brooks, C., Rew, A. G., \&Ritson, S. (2001). A trading strategy based on the lead-lag relationship between the spot index and futures contract for the FTSE 100. International Journal of Forecasting, 17(1), 31-44.

Lin, C. C., Chen, S. Y., Hwang, D. Y., \& Lin, C. F. (2002). Does index futures dominate index spot? Evidence from Taiwan market. Review of Pacific Basin Financial Markets and Policies, 5(02), 255-275.

Hung, M. W., Lee, C. F., \& So, L. C. (2003). Impact of foreign-listed single stock futures on the domestic underlying stock markets. Applied Economics Letters, 10(9), 567-574. 
Zhong, M., Darrat, A. F., \& Otero, R. (2004). Price discovery and volatility spillovers in index futures markets: Some evidence from Mexico. Journal of Banking \& Finance, 28(12), $3037-$ 3054.

Khan, S. U. (2006). Role of the futures market on volatility and price discovery of the spot market: Evidence from Pakistan's stock market. Lahore Journal of Economics, 11(2), 107-121. Karathanassis, G., \&Sogiakas, V. (2007). Spill Over Effects of Futures Contracts Initiation on the Cash Market: A Comparative Analysis.

Floros, C., \&Vougas, D. (2007). Lead-lag relationship between futures and spot markets in Greece: 1999- 2001. International Research Journal of Finance and Economics, (7), 168-174.

Kavussanos, M. G., Visvikis, I. D., \&Alexakis, P. D. (2008). The Lead-Lag Relationship between Cash and Stock Index Futures in a New Market. European Financial Management, 14(5), 10071025 .

Sariannidis, N., \&Drimbetas, E. (2008). Impact of international volatility and the introduction of Individual Stock Futures on the volatility of a small market. European Research Studies Journal, 11(3).

Madarassy Akin, R., \&Fischmar, D. (2009). Market Efficiency and the Lead-Lag Relationship between Futures and Spot Rates for the Australian Dollar. Pennsylvania Economic Review.

De Beer, J. (2009). Changes in the volatility level and structure of shares post single stock futures trading.

Swaroop Debasish, S. (2009). An econometric analysis of the lead-lag relationship between India's NSE Nifty and its derivative contracts. The Journal of Risk Finance, 10(4), 350-364.

Mallikarjunappa, T., \&Afsal, E. M. (2010). Price Discovery Process and Volatility Spillovers in Spot and Futures Markets: Evidences of Individual Stocks. Vikalpa, 35(2), 49-62.

Karathanassis, G. A., \&Sogiakas, V. I. (2010). Spillover effects of futures contracts initiation on the cash market: a regime shift approach. Review of Quantitative Finance and Accounting, 34(1), 95-143.

Jithendranathan, T., \&Vang, D. O. (2010). Impact of Single Stock Futures on the Volatility of Underlying Russian Stocks. Global Business and Financial Review.

Jackline, S., \& Deo, M. (2011). Lead-lag relationship between the futures and spot prices. Journal of Economics and International Finance, 3(7), 424-427.

Theissen, E. (2012). Price discovery in spot and futures markets: a reconsideration. The European Journal of Finance, 18(10), 969-987.

Choudhary, K., \& Bajaj, S. (2012). Intraday lead/lag relationships between the futures and spot market. Eurasian Journal of Business and Economics, 5(9), 165-186.

Jamal, N., \&Fraz, A. (2013). Relationship of Single Stock Futures with the Spot Price: Evidence from Karachi Stock Exchange. RESEARCH JOURNAL of THE INSTITUTE OF BUSINESS ADMINISTRATION KARACHI-PAKISTAN, 8(1), 52.

Ullah, H., \& Shah, A. (2013). Lead-Lag Relationship in Spot and Future Market: Evidence from Pakistani Stock Market KSE-100 index. Business Review, 8(1), 135-148. 
Table 1. Descriptive Statistics

\begin{tabular}{|c|c|c|c|c|c|c|c|}
\hline Companies & & Mean & Median & Maximum & Minimum & Std. Dev. & Skewness \\
\hline \multirow{2}{*}{ ACBL } & $S$ & -0.012 & 0.005 & 0.240 & -0.653 & 0.142 & -1.413 \\
\hline & $\mathrm{F}$ & -0.012 & 0.000 & 0.439 & -0.637 & 0.139 & -1.063 \\
\hline \multirow{2}{*}{ ATRL } & $\mathrm{S}$ & -0.003 & 0.000 & 0.409 & -0.615 & 0.165 & -0.288 \\
\hline & $\mathrm{F}$ & -0.003 & 0.000 & 0.419 & -0.599 & 0.165 & -0.216 \\
\hline \multirow{2}{*}{ BAFL } & $\mathrm{S}$ & -0.011 & 0.000 & 0.259 & -0.625 & 0.129 & -1.222 \\
\hline & $\mathrm{F}$ & -0.011 & 0.000 & 0.405 & -0.610 & 0.132 & -0.840 \\
\hline \multirow{2}{*}{ BAHL } & $S$ & 0.003 & 0.023 & 0.164 & -0.301 & 0.089 & -1.286 \\
\hline & $\mathrm{F}$ & 0.004 & 0.001 & 0.174 & -0.289 & 0.076 & -1.039 \\
\hline \multirow{2}{*}{ BOP } & $\mathrm{S}$ & -0.026 & -0.006 & 0.413 & -0.630 & 0.177 & -0.735 \\
\hline & $\mathrm{F}$ & -0.015 & 0.000 & 0.348 & -0.614 & 0.162 & -0.994 \\
\hline \multirow{2}{*}{ DGKC } & $\mathrm{S}$ & -0.010 & 0.000 & 0.322 & -0.613 & 0.165 & -1.039 \\
\hline & $\mathrm{F}$ & -0.010 & -0.007 & 0.503 & -0.605 & 0.169 & -0.468 \\
\hline \multirow{2}{*}{ DSFL } & $S$ & -0.020 & -0.025 & 0.549 & -0.328 & 0.150 & 0.982 \\
\hline & $\mathrm{F}$ & -0.020 & -0.010 & 0.587 & -0.409 & 0.157 & 0.774 \\
\hline \multirow{2}{*}{ ENGRO } & $\mathrm{S}$ & 0.005 & 0.006 & 0.288 & -0.626 & 0.126 & -1.151 \\
\hline & $\mathrm{F}$ & 0.005 & 0.000 & 0.288 & -0.617 & 0.120 & -1.837 \\
\hline \multirow{2}{*}{ FABL } & S & -0.010 & 0.004 & 0.330 & -0.732 & 0.158 & -1.848 \\
\hline & $\mathrm{F}$ & -0.010 & 0.001 & 0.326 & -0.716 & 0.164 & -1.518 \\
\hline \multirow{2}{*}{ FCCL } & S & -0.035 & -0.012 & 0.296 & -0.384 & 0.137 & -0.243 \\
\hline & F & -0.036 & 0.000 & 0.242 & -0.268 & 0.110 & 0.039 \\
\hline \multirow{2}{*}{ FFBL } & $S$ & 0.005 & 0.017 & 0.222 & -0.569 & 0.106 & -1.457 \\
\hline & $\mathrm{F}$ & 0.005 & 0.008 & 0.352 & -0.358 & 0.100 & -0.285 \\
\hline \multirow{2}{*}{ FFC } & $S$ & 0.000 & 0.013 & 0.385 & -0.532 & 0.105 & -1.219 \\
\hline & $\mathrm{F}$ & 0.001 & 0.000 & 0.979 & -0.924 & 0.168 & 0.210 \\
\hline \multirow{2}{*}{ HUBC } & $S$ & 0.003 & 0.000 & 0.247 & -0.421 & 0.084 & -1.029 \\
\hline & $\mathrm{F}$ & 0.003 & 0.000 & 0.248 & -0.343 & 0.073 & -0.686 \\
\hline \multirow{2}{*}{ ICI } & $S$ & -0.011 & 0.000 & 0.311 & -0.614 & 0.144 & -1.453 \\
\hline & $\mathrm{F}$ & -0.011 & 0.000 & 0.311 & -0.599 & 0.147 & -1.054 \\
\hline \multirow{2}{*}{ КАРСО } & $S$ & 0.002 & 0.003 & 0.209 & -0.272 & 0.077 & -0.646 \\
\hline & $\mathrm{F}$ & 0.002 & 0.000 & 0.367 & -0.252 & 0.072 & 0.556 \\
\hline \multirow{2}{*}{ LUCK } & $S$ & 0.020 & 0.030 & 0.301 & -0.614 & 0.122 & -1.385 \\
\hline & $\mathrm{F}$ & 0.020 & 0.000 & 0.370 & -0.599 & 0.131 & -0.878 \\
\hline \multirow[t]{2}{*}{ MCB } & $S$ & 0.014 & 0.011 & 0.294 & -0.615 & 0.124 & -1.251 \\
\hline & $\mathrm{F}$ & 0.014 & 0.000 & 0.293 & -0.600 & 0.128 & -1.191 \\
\hline MLCF & $\mathrm{S}$ & -0.022 & -0.028 & 0.227 & -0.357 & 0.122 & -0.238 \\
\hline
\end{tabular}




\begin{tabular}{|c|c|c|c|c|c|c|c|}
\hline \multirow{3}{*}{ NBP } & $\mathrm{F}$ & -0.017 & -0.014 & 0.222 & -0.295 & 0.113 & -0.038 \\
\hline & $S$ & 0.004 & 0.009 & 0.367 & -0.614 & 0.156 & -0.843 \\
\hline & $\mathrm{F}$ & 0.004 & 0.021 & 0.372 & -0.599 & 0.159 & -1.045 \\
\hline \multirow{2}{*}{ NML } & $S$ & 0.003 & 0.014 & 0.403 & -0.515 & 0.162 & -0.551 \\
\hline & $\mathrm{F}$ & 0.004 & 0.000 & 0.946 & -1.101 & 0.247 & -0.479 \\
\hline \multirow{2}{*}{ OGDCL } & $\mathrm{S}$ & 0.009 & 0.005 & 0.374 & -0.636 & 0.127 & -1.555 \\
\hline & $\mathrm{F}$ & 0.009 & 0.018 & 0.885 & -1.071 & 0.244 & -0.730 \\
\hline \multirow{2}{*}{ PIOC } & $S$ & -0.031 & -0.028 & 0.207 & -0.379 & 0.135 & -0.275 \\
\hline & $\mathrm{F}$ & -0.027 & 0.000 & 0.209 & -0.341 & 0.134 & -0.291 \\
\hline \multirow{2}{*}{ POL } & $\mathrm{S}$ & 0.002 & 0.017 & 0.350 & -0.615 & 0.153 & -1.684 \\
\hline & $\mathrm{F}$ & 0.002 & 0.008 & 0.302 & -0.600 & 0.138 & -1.198 \\
\hline \multirow{2}{*}{ PPL } & $S$ & 0.008 & 0.003 & 0.612 & -0.655 & 0.156 & -0.147 \\
\hline & $\mathrm{F}$ & 0.009 & 0.000 & 0.621 & -0.638 & 0.157 & -0.121 \\
\hline \multirow{2}{*}{ PSO } & $\mathrm{S}$ & 0.001 & 0.000 & 0.326 & -0.615 & 0.120 & -1.561 \\
\hline & $\mathrm{F}$ & 0.001 & 0.000 & 0.326 & -0.600 & 0.124 & -1.332 \\
\hline \multirow{2}{*}{ PTC } & $S$ & -0.003 & 0.000 & 0.319 & -0.623 & 0.113 & -0.941 \\
\hline & $\mathrm{F}$ & -0.002 & 0.000 & 0.359 & -0.617 & 0.109 & -1.225 \\
\hline \multirow{2}{*}{ SNGP } & $\mathrm{S}$ & -0.011 & -0.020 & 0.423 & -0.437 & 0.134 & 0.388 \\
\hline & $\mathrm{F}$ & -0.011 & -0.016 & 0.420 & -0.421 & 0.134 & -0.068 \\
\hline \multirow{2}{*}{ SSGC } & $S$ & -0.013 & -0.004 & 0.302 & -0.770 & 0.144 & -2.134 \\
\hline & $\mathrm{F}$ & -0.013 & 0.000 & 0.300 & -0.731 & 0.141 & -1.972 \\
\hline \multirow{2}{*}{ TELE / } & 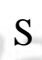 & -0.028 & -0.034 & 0.293 & -0.363 & 0.144 & 0.119 \\
\hline & $\mathrm{F}$ & -0.012 & -0.003 & 0.280 & -0.353 & 0.134 & 0.051 \\
\hline \multirow{2}{*}{ UBL } & $S$ & 0.001 & 0.011 & 0.260 & -0.615 & 0.127 & -1.575 \\
\hline & $\mathrm{F}$ & 0.001 & 0.000 & 0.415 & -0.599 & 0.125 & -1.291 \\
\hline
\end{tabular}

Table 2. Bivariate Co-integration Analysis

Maximum Eigen Value

\begin{tabular}{|l|l|l|l|l|l|}
\hline Companies & $\begin{array}{l}\text { Hypothesized } \\
\text { No. of CE(s) }\end{array}$ & Eigenvalue & $\begin{array}{l}\text { Trace } \\
\text { Statistic }\end{array}$ & $\begin{array}{l}\mathbf{0 . 0 5} \text { Critical } \\
\text { Value }\end{array}$ & Prob.** \\
\hline \multirow{2}{*}{ ACBL } & None $*$ & 0.136456 & 17.01839 & 14.2646 & 0.0179 \\
& At most 1 & 0.012578 & 1.46826 & 3.841466 & 0.2256 \\
ATRL & None & 0.135283 & 10.75613 & 14.2646 & 0.1669 \\
& At most 1 * & 0.085131 & 6.584102 & 3.841466 & 0.0103 \\
BAFL & None & 0.036528 & 4.614293 & 14.2646 & 0.7895 \\
& At most 1 & 0.013045 & 1.628207 & 3.841466 & 0.202 \\
BAHL & None $*$ & 0.244672 & 17.67797 & 14.2646 & 0.0139 \\
& At most 1 & 0.025364 & 1.618574 & 3.841466 & 0.2033
\end{tabular}




\begin{tabular}{|c|c|c|c|c|c|}
\hline \multirow{2}{*}{ BOP } & None & 0.055661 & 3.951611 & 14.2646 & 0.8644 \\
\hline & At most 1 & 0.002788 & 0.192632 & 3.841466 & 0.6607 \\
\hline \multirow{2}{*}{ DGKC } & None * & 0.273851 & 21.11998 & 14.2646 & 0.0035 \\
\hline & At most 1 & 0.027109 & 1.813891 & 3.841466 & 0.178 \\
\hline \multirow{2}{*}{ DSFL } & None $*$ & 0.403321 & 24.78604 & 14.2646 & 0.0008 \\
\hline & At most 1 & 0.040577 & 1.988327 & 3.841466 & 0.1585 \\
\hline \multirow{2}{*}{ ENGRO } & None & 0.099654 & 13.01709 & 14.2646 & 0.078 \\
\hline & At most $1 *$ & 0.03465 & 4.372757 & 3.841466 & 0.0365 \\
\hline \multirow{2}{*}{ FABL } & None * & 0.211322 & 23.50231 & 14.2646 & 0.0013 \\
\hline & At most 1 & 0.011127 & 1.107795 & 3.841466 & 0.2926 \\
\hline \multirow{2}{*}{ FCCL } & None & 0.408012 & 12.58247 & 14.2646 & 0.0906 \\
\hline & At most $1 *$ & 0.297954 & 8.490165 & 3.841466 & 0.0036 \\
\hline \multirow{2}{*}{ FFBL } & None $*$ & 0.239243 & 33.90667 & 14.2646 & 0 \\
\hline & At most $1 *$ & 0.036799 & 4.649116 & 3.841466 & 0.0311 \\
\hline \multirow{2}{*}{ FFC } & None $*$ & 0.333581 & 49.10627 & 14.2646 & 0 \\
\hline & At most $1 *$ & 0.056571 & 7.046379 & 3.841466 & 0.0079 \\
\hline \multirow{2}{*}{ HUBC } & None $*$ & 0.274078 & 39.71876 & 14.2646 & 0 \\
\hline & At most 1 & 0.006715 & 0.835423 & 3.841466 & 0.3607 \\
\hline \multirow{2}{*}{ ICI } & None & 0.220997 & 9.989616 & 14.2646 & 0.2126 \\
\hline & At most $1 *$ & 0.125453 & 5.36199 & 3.841466 & 0.0206 \\
\hline \multirow{2}{*}{ КАРСО } & None $*$ & 0.190164 & 22.99069 & 14.2646 & 0.0017 \\
\hline & At most $1 *$ & 0.037886 & 4.209819 & 3.841466 & 0.0402 \\
\hline \multirow{2}{*}{ LUCK } & None * & 0.206219 & 27.48281 & 14.2646 & 0.0003 \\
\hline & At most 1 & 0.004555 & 0.543258 & 3.841466 & 0.4611 \\
\hline \multirow{2}{*}{ МCB } & None $*$ & 0.167105 & 22.67307 & 14.2646 & 0.0019 \\
\hline & At most $1 *$ & 0.03646 & 4.605527 & 3.841466 & 0.0319 \\
\hline \multirow{2}{*}{ MLCF } & None $*$ & 0.447838 & 27.31999 & 14.2646 & 0.0003 \\
\hline & At most 1 & 0.047322 & 2.230005 & 3.841466 & 0.1354 \\
\hline \multirow{2}{*}{ NBP } & None $*$ & 0.429679 & 37.62426 & 14.2646 & 0 \\
\hline & At most 1 & 0.02584 & 1.754062 & 3.841466 & 0.1854 \\
\hline \multirow{2}{*}{ NML } & None $*$ & 0.364668 & 34.92779 & 14.2646 & 0 \\
\hline & At most 1 & 0.042772 & 3.365976 & 3.841466 & 0.0666 \\
\hline \multirow{2}{*}{ OGDCL } & None $*$ & 0.366274 & 28.73673 & 14.2646 & 0.0001 \\
\hline & At most $1 *$ & 0.069757 & 4.555465 & 3.841466 & 0.0328 \\
\hline \multirow{2}{*}{ PIOC } & None & 0.296082 & 9.83061 & 14.2646 & 0.2233 \\
\hline & At most $1 *$ & 0.228309 & 7.256772 & 3.841466 & 0.0071 \\
\hline POL & None $*$ & 0.338425 & 29.74547 & 14.2646 & 0.0001 \\
\hline
\end{tabular}




\begin{tabular}{|c|c|c|c|c|c|}
\hline \multirow{3}{*}{ PPL } & At most $1 *$ & 0.059073 & 4.384049 & 3.841466 & 0.0363 \\
\hline & None $*$ & 0.28 & 22.66678 & 14.2646 & 0.0019 \\
\hline & At most $1 *$ & 0.107949 & 7.882035 & 3.841466 & 0.005 \\
\hline \multirow{2}{*}{ PSO } & None $*$ & 0.268263 & 22.17573 & 14.2646 & 0.0023 \\
\hline & At most $1 *$ & 0.08632 & 6.409521 & 3.841466 & 0.0113 \\
\hline \multirow{2}{*}{ PTC } & None & 0.03652 & 4.614293 & 14.2646 & 0.7895 \\
\hline & At most 1 & 0.013045 & 1.628207 & 3.841466 & 0.202 \\
\hline \multirow{2}{*}{ SNGP } & None $*$ & 0.222244 & 1.628207 & 14.2646 & 0.0158 \\
\hline & At most 1 & 0.002375 & 0.164083 & 3.841466 & 0.6854 \\
\hline \multirow{2}{*}{ SSGC } & None $*$ & 0.333778 & 23.55566 & 14.2646 & 0.0013 \\
\hline & At most 1 & 0.005189 & 0.301753 & 3.841466 & 0.5828 \\
\hline \multirow{2}{*}{ TELE } & None $*$ & 0.416387 & 23.69472 & 14.2646 & 0.0012 \\
\hline & At most $1 *$ & 0.09338 & 4.313394 & 3.841466 & 0.0378 \\
\hline \multirow{2}{*}{ UBL } & None & 0.159097 & 12.82263 & 14.2646 & 0.0834 \\
\hline & At most 1 & 0.034959 & 2.633291 & 3.841466 & 0.1046 \\
\hline
\end{tabular}

Table 3. Granger Causality Test

\begin{tabular}{|l|l|l|l|l|}
\hline Companies & Null Hypothesis: & Obs & F-Statistic & Prob. \\
\hline \multirow{2}{*}{ ACBL } & RS is not granger caused by Rf & 116 & 8.88894 & 0.0035 \\
& RF is not granger caused by RS & & 0.23129 & 0.6315 \\
BARL & RS is not granger caused by Rf & 74 & 4.56107 & 0.0362 \\
& RF is not granger caused by RS & & -1.07099 & 0.3042 \\
BAHL & RS is not granger caused by Rf & 99 & 0.59786 & 0.4413 \\
& RF is not granger caused by RS & & 0.90561 & 0.3437 \\
BOP & RS is not granger caused by Rf & 63 & 2.34068 & 0.1313 \\
& RF is not granger caused by RS & & 0.03498 & 0.8523 \\
DGKC & RS is not granger caused by Rf & 69 & 5.2361 & 0.0253 \\
& RF is not granger caused by RS & & 2.51763 & 0.1174 \\
DSFL & RS is not granger caused by Rf & 66 & 0.0245 & 0.8761 \\
& RF is not granger caused by RS & & 4.49144 & 0.038 \\
ENGRO & RS is not granger caused by Rf & 48 & 1.65938 & 0.2043 \\
FABL & RF is not granger caused by RS & & 2.62864 & 0.1119 \\
FCCL & RS is not granger caused by Rf & \multirow{2}{*}{124} & 0.39418 & 0.5313 \\
& RF is not granger caused by RS & & 5.51755 & 0.0204 \\
& RS is not granger caused by Rf & 61 & 3.78698 & 0.0565 \\
& RF is not granger caused by RS & & 0.97165 & 0.3284 \\
& RS is not granger caused by Rf & 24 & 1.16936 & 0.2918
\end{tabular}




\begin{tabular}{|c|c|c|c|c|}
\hline \multirow{3}{*}{ FFBL } & $\mathrm{RF}$ is not granger caused by $\mathrm{RS}$ & & 1.82375 & 0.1912 \\
\hline & $\mathrm{RS}$ is not granger caused by $\mathrm{Rf}$ & 124 & 0.58496 & 0.4459 \\
\hline & $\mathrm{RF}$ is not granger caused by $\mathrm{RS}$ & & 4.04142 & 0.0466 \\
\hline \multirow{3}{*}{ FFC } & $\mathrm{RS}$ is not granger caused by $\mathrm{Rf}$ & 124 & 0.28926 & 0.5917 \\
\hline & $\mathrm{RF}$ is not granger caused by $\mathrm{RS}$ & & 1.24783 & 0.2662 \\
\hline & $\mathrm{RS}$ is not granger caused by $\mathrm{Rf}$ & 124 & 1.26462 & 0.263 \\
\hline HUBC & $\mathrm{RF}$ is not granger caused by $\mathrm{RS}$ & & 14.7126 & $2.00 \mathrm{E}-04$ \\
\hline \multirow{2}{*}{ ICI } & $\mathrm{RS}$ is not granger caused by $\mathrm{Rf}$ & 40 & 0.52976 & 0.4713 \\
\hline & $\mathrm{RF}$ is not granger caused by $\mathrm{RS}$ & & 2.07555 & 0.1581 \\
\hline \multirow{2}{*}{ КАРCO } & $\mathrm{RS}$ is not granger caused by $\mathrm{Rf}$ & 109 & 4.30534 & 0.0404 \\
\hline & $\mathrm{RF}$ is not granger caused by $\mathrm{RS}$ & & 0.91409 & 0.3412 \\
\hline \multirow{2}{*}{ LUCK } & $\mathrm{RS}$ is not granger caused by $\mathrm{Rf}$ & 119 & 0.09515 & 0.7583 \\
\hline & $\mathrm{RF}$ is not granger caused by $\mathrm{RS}$ & & 7.44886 & 0.0073 \\
\hline \multirow{2}{*}{ МСB } & $\mathrm{RS}$ is not granger caused by $\mathrm{Rf}$ & 124 & 0.14969 & 0.6995 \\
\hline & $\mathrm{RF}$ is not granger caused by $\mathrm{RS}$ & & 0.51026 & 0.4764 \\
\hline \multirow{2}{*}{ MLCF } & $\mathrm{RS}$ is not granger caused by $\mathrm{Rf}$ & 46 & 0.66809 & 0.4182 \\
\hline & $\mathrm{RF}$ is not granger caused by $\mathrm{RS}$ & & 1.4112 & 0.2414 \\
\hline \multirow{2}{*}{ NBP } & $\mathrm{RS}$ is not granger caused by $\mathrm{Rf}$ & 67 & 0.20997 & 0.6483 \\
\hline & $\mathrm{RF}$ is not granger caused by RS & & 1.35918 & 0.248 \\
\hline \multirow{2}{*}{ NML } & $\mathrm{RS}$ is not granger caused by $\mathrm{Rf}$ & 77 & 0.00122 & 0.9722 \\
\hline & $\mathrm{RF}$ is not granger caused by $\mathrm{RS}$ & & 11.0447 & 0.0014 \\
\hline \multirow{2}{*}{ OGDCL } & $\mathrm{RS}$ is not granger caused by $\mathrm{Rf}$ & 66 & 0.08576 & 0.7706 \\
\hline & $\mathrm{RF}$ is not granger caused by RS & & 4.23625 & 0.0437 \\
\hline \multirow{2}{*}{ PIOC } & $\mathrm{RS}$ is not granger caused by $\mathrm{Rf}$ & 28 & 0.36595 & 0.5507 \\
\hline & $\mathrm{RF}$ is not granger caused by $\mathrm{RS}$ & & 0.22382 & 0.6402 \\
\hline \multirow{2}{*}{ POL } & $\mathrm{RS}$ is not granger caused by $\mathrm{Rf}$ & 72 & 13.9783 & 0.0004 \\
\hline & $\mathrm{RF}$ is not granger caused by $\mathrm{RS}$ & & 0.08898 & 0.7664 \\
\hline \multirow{2}{*}{ PPL } & $\mathrm{RS}$ is not granger caused by $\mathrm{Rf}$ & 69 & 0.00815 & 0.9283 \\
\hline & $\mathrm{RF}$ is not granger caused by $\mathrm{RS}$ & & 0.09844 & 0.7547 \\
\hline \multirow{2}{*}{ PSO } & $\mathrm{RS}$ is not granger caused by $\mathrm{Rf}$ & 72 & 3.58565 & 0.0625 \\
\hline & $\mathrm{RF}$ is not granger caused by $\mathrm{RS}$ & & 0.1186 & 0.7316 \\
\hline \multirow{2}{*}{ PTC } & $\mathrm{RS}$ is not granger caused by $\mathrm{Rf}$ & 124 & 0.2191 & 0.6406 \\
\hline & $\mathrm{RF}$ is not granger caused by $\mathrm{RS}$ & & 2.86777 & 0.0929 \\
\hline \multirow{2}{*}{ SNGP } & $\mathrm{RS}$ is not granger caused by $\mathrm{Rf}$ & 69 & 4.03581 & 0.0486 \\
\hline & $\mathrm{RF}$ is not granger caused by $\mathrm{RS}$ & & 0.19344 & 0.6615 \\
\hline \multirow{2}{*}{ SSGC } & $\mathrm{RS}$ is not granger caused by $\mathrm{Rf}$ & 58 & $9.60 \mathrm{E}-04$ & 0.9754 \\
\hline & $\mathrm{RF}$ is not granger caused by $\mathrm{RS}$ & & 0.22137 & 0.6399 \\
\hline TELE & $\mathrm{RS}$ is not granger caused by $\mathrm{Rf}$ & 45 & 2.33951 & 0.1336 \\
\hline
\end{tabular}




\begin{tabular}{|l|l|l|l|l|} 
& RF is not granger caused by RS & & 0.02171 & 0.8836 \\
UBL & RS is not granger caused by Rf & 74 & 0.13327 & 0.7162 \\
& RF is not granger caused by RS & & 0.95739 & 0.3312 \\
\hline
\end{tabular}

Table 5. Vector error correction estimates

\begin{tabular}{|c|c|c|c|c|c|c|c|c|c|c|c|c|c|}
\hline Comp & $\begin{array}{l}\text { Err } \\
\text { Corr } \\
\end{array}$ & ointEq1 & SE & $\begin{array}{l}\begin{array}{l}\text { T } \\
\text { stats }\end{array} \\
\end{array}$ & $\begin{array}{l}\mathrm{D}(\mathbf{S}(- \\
\text { 1)) }\end{array}$ & SE & $\begin{array}{l}\begin{array}{l}\text { T } \\
\text { stats }\end{array} \\
\end{array}$ & $\begin{array}{l}\text { D(F(- } \\
\text { 1)) }\end{array}$ & SE & $\begin{array}{l}\mathbf{T} \\
\text { stats }\end{array}$ & C & SE & \begin{tabular}{|l} 
T \\
stats
\end{tabular} \\
\hline \multirow[t]{2}{*}{ ACBL } & $\mathrm{D}(\mathrm{S})$ & 162 & 0.161 & [1.01] & -0.190 & 0.171 & 1.11] & 0.378 & 0.174 & [ 2.16] & 0.005 & 0.006 & {$[0.82]$} \\
\hline & $\mathrm{D}(\mathrm{F})$ & 0.212 & 0.163 & $1.30]$ & -0.031 & 0.173 & [- & 0.141 & 0.176 & {$[0.80]$} & 0.005 & 0.006 & {$[0.87]$} \\
\hline \multirow[t]{2}{*}{ ATRL } & $\mathrm{D}(\mathrm{S})$ & 0.53 & 0.236 & 2.28] & -1.035 & 0.403 & $2.56]$ & 1.155 & 0.407 & [ 2.84] & 0.002 & 0.008 & {$[0.25]$} \\
\hline & $\mathrm{D}(\mathrm{F})$ & 0.674 & 0.234 & 2.87] & -0.777 & 0.401 & 1.93] & 0.939 & 0.404 & [ 2.32] & 0.002 & 0.008 & {$[0.24]$} \\
\hline \multirow[t]{2}{*}{ BAFL } & $\mathrm{D}(\mathrm{S})$ & 0.022 & 0.057 & $0.39]$ & -0.044 & 0.145 & $0.30]$ & 0.081 & 0.150 & {$[0.54]$} & -.002 & 0.004 & {$[0.34]$} \\
\hline & $\mathrm{D}(\mathrm{F})$ & 0.087 & 0.054 & 1.61] & 0.177 & -.137 & 1.28] & -0.104 & 0.142 & {$[0.73]$} & 0.001 & 0.004 & {$[0.21]$} \\
\hline \multirow[t]{2}{*}{ BAHL } & $\mathrm{D}(\mathrm{S})$ & -0.720 & 0.331 & [2.17] & -0.055 & 0.264 & $0.20]$ & 0.026 & 0.291 & {$[0.08]$} & 0.008 & 0.010 & $0.84]$ \\
\hline & $\mathrm{D}(\mathrm{F})$ & 012 & 0.293 & [0.04] & .040 & 0.234 & $0.17]$ & -0.075 & 0.258 & {$[0.29]$} & 0.008 & 0.009 & $0.95]$ \\
\hline \multirow[t]{2}{*}{ BOP } & $\mathrm{D}(\mathrm{S})$ & 0.100 & 0.177 & $0.56]$ & -0.494 & 0.274 & 1.80] & 0.686 & 0.301 & [ 2.27] & 0.012 & 0.009 & {$[1.25]$} \\
\hline & $\mathrm{D}(\mathrm{F})$ & 0.227 & 0.162 & $1.40]$ & -0.516 & 0.250 & $2.06]$ & 0.690 & 0.275 & [ 2.50] & 0.008 & 0.008 & {$[0.97]$} \\
\hline \multirow[t]{2}{*}{ DGKC } & $\mathrm{D}(\mathrm{S})$ & -0.078 & 0.465 & {$[0.16]$} & 0.296 & 0.393 & $0.75]$ & 0.009 & 0.371 & [ 0.02$]$ & 0.003 & 0.009 & {$[0.39]$} \\
\hline & $\mathrm{D}(\mathrm{F})$ & 0.672 & 0.460 & $1.46]$ & 0.292 & 0.390 & 0.74] & -0.016 & 0.368 & {$[0.04]$} & 0.004 & 0.009 & {$[0.40]$} \\
\hline \multirow[t]{2}{*}{ DSFL } & $\mathrm{D}(\mathrm{S})$ & -1.009 & 0.555 & [1.82] & -0.206 & .455 & $0.45]$ & -0.031 & 0.471 & {$[0.06]$} & 0.009 & 0.009 & {$[0.92]$} \\
\hline & $\mathrm{D}(\mathrm{F})$ & -0.209 & 0.591 & {$[0.35]$} & -0.561 & 0.485 & 1.15] & 0.256 & 0.502 & {$[0.50]$} & 0.009 & 0.010 & {$[0.92]$} \\
\hline \multirow[t]{2}{*}{ ENGRO } & $\mathrm{D}(\mathrm{S})$ & -0.009 & 0.103 & {$[0.08]$} & -0.132 & 0.137 & $0.96]$ & -0.086 & 0.138 & {$[0.61]$} & 0.003 & 0.005 & $0.56]$ \\
\hline & $\mathrm{D}(\mathrm{F})$ & 0.224 & 0.095 & 2.37] & 0.146 & 0.126 & 1.15] & -0.253 & 0.127 & {$[1.99]$} & 0.003 & 0.005 & $0.59]$ \\
\hline \multirow[t]{2}{*}{ FABL } & $\mathrm{D}(\mathrm{S})$ & 0.365 & 0.255 & 1.43] & -0.611 & 0.286 & 2.13] & 0.570 & 0.257 & [ 2.22] & 0.001 & 0.006 & {$[0.10]$} \\
\hline & $\mathrm{D}(\mathrm{F})$ & 0.868 & 0.270 & $3.21]$ & -0.638 & 0.302 & $\begin{array}{l}{[-} \\
2.10]\end{array}$ & 0.556 & 0.272 & [ 2.04] & 0.001 & 0.007 & {$[0.10]$} \\
\hline
\end{tabular}




\begin{tabular}{|c|c|c|c|c|c|c|c|c|c|c|c|c|c|}
\hline \multirow[t]{2}{*}{ FCCL } & $\mathrm{D}(\mathrm{S})$ & 0.368 & 0.163 & $2.26]$ & -0.566 & 0.278 & $\begin{array}{l}{[-} \\
2.03]\end{array}$ & 0.509 & 0.312 & [ 1.63$]$ & 0.014 & 0.012 & [1.13] \\
\hline & $\mathrm{D}(\mathrm{F})$ & 0.405 & 0.109 & $\begin{array}{l}{[} \\
3.71]\end{array}$ & -0.052 & 0.186 & $\begin{array}{l}{[-} \\
0.28]\end{array}$ & 0.130 & 0.209 & {$[0.62]$} & 0.013 & 0.008 & [1.59] \\
\hline \multirow[t]{2}{*}{ FFBL } & $\mathrm{D}(\mathrm{S})$ & -0.027 & 0.181 & [0.15] & 0.077 & 0.186 & $0.41]$ & -0.139 & 0.186 & {$[0.75]$} & 0.003 & 0.004 & $0.61]$ \\
\hline & $\mathrm{D}(\mathrm{F})$ & 0.491 & 0.162 & $3.02]$ & 0.020 & 0.167 & $0.11]$ & -0.039 & 0.166 & {$[0.23]$} & 0.002 & 0.004 & $0.66]$ \\
\hline \multirow[t]{2}{*}{ FFC } & $\mathrm{D}(\mathrm{S})$ & -0.042 & 0.107 & [0.39] & -0.380 & 0.109 & $\begin{array}{l}{[-} \\
3.47]\end{array}$ & 0.006 & 0.076 & [ 0.07] & 0.001 & 0.004 & $\begin{array}{l}{[} \\
0.15]\end{array}$ \\
\hline & $\mathrm{D}(\mathrm{F})$ & 0.934 & 0.144 & $\begin{array}{l}{[} \\
6.50]\end{array}$ & -0.379 & 0.147 & $\begin{array}{l}{[-} \\
2.58]\end{array}$ & -0.011 & 0.102 & [0.10] & 0.001 & 0.005 & $\begin{array}{l}{[} \\
0.12]\end{array}$ \\
\hline \multirow[t]{2}{*}{ HUBC } & $\mathrm{D}(\mathrm{S})$ & -0.381 & 0.181 & [2.10] & 0.125 & 0.151 & $0.82]$ & -0.017 & 0.153 & {$[0.10]$} & 0.001 & 0.003 & $0.43]$ \\
\hline & $\mathrm{D}(\mathrm{F})$ & 0.379 & 0.148 & $\begin{array}{l}{[} \\
2.56]\end{array}$ & 0.157 & 0.124 & $\begin{array}{l}{[} \\
1.26]\end{array}$ & -0.057 & 0.125 & {$[0.45]$} & 0.001 & 0.003 & $\begin{array}{l}{[} \\
0.54]\end{array}$ \\
\hline \multirow[t]{2}{*}{ ICI } & $\mathrm{D}(\mathrm{S})$ & -0.015 & 0.005 & [3.08] & 0.033 & 0.307 & $0.10]$ & 0.408 & 0.299 & [ 1.36] & 0.003 & 0.009 & [0.34] \\
\hline & $\mathrm{D}(\mathrm{F})$ & -0.015 & 0.005 & [3.01] & 0.415 & 0.311 & 1.33] & 0.047 & 0.303 & {$[0.15]$} & 0.004 & 0.009 & {$[0.41]$} \\
\hline \multirow[t]{2}{*}{ КАРСО } & $\mathrm{D}(\mathrm{S})$ & -0.082 & 0.106 & {$[0.78]$} & -0.261 & 0.119 & $\begin{array}{l}{[-} \\
2.18]\end{array}$ & 0.190 & 0.123 & [ 1.54$]$ & 0.002 & 0.003 & 0.69] \\
\hline & $\mathrm{D}(\mathrm{F})$ & 0.310 & 0.105 & 2.96] & -0.064 & 0.118 & $\begin{array}{l}{[-} \\
0.54]\end{array}$ & -0.044 & 0.122 & {$[0.35]$} & 0.001 & 0.003 & {$\left[\begin{array}{l}{[} \\
0.26]\end{array}\right.$} \\
\hline \multirow[t]{2}{*}{ LUCK } & $\mathrm{D}(\mathrm{S})$ & 0.037 & 0.248 & $\begin{array}{l}{[} \\
0.15]\end{array}$ & 0.197 & 0.241 & $\begin{array}{l}{[} \\
0.820]\end{array}$ & 0.077 & 0.227 & {$[0.33]$} & 0.006 & 0.005 & $\begin{array}{l}{[} \\
1.30]\end{array}$ \\
\hline & $\mathrm{D}(\mathrm{F})$ & 0.589 & 0.258 & [2.28] & 0.282 & 0.250 & [ 1.12$]$ & 0.000 & 0.236 & {$[0.00]$} & 0.006 & 0.005 & [ 1.25$]$ \\
\hline \multirow[t]{2}{*}{ MCB } & $\mathrm{D}(\mathrm{S})$ & 0.394 & 0.226 & [ 1.74$]$ & -0.295 & 0.287 & $\begin{array}{l}{[-} \\
1.02]\end{array}$ & 0.301 & 0.276 & [ 1.08$]$ & 0.006 & 0.005 & [ 1.30$]$ \\
\hline & $\mathrm{D}(\mathrm{F})$ & 0.703 & 0.225 & $3.12]$ & -0.197 & 0.286 & $0.69]$ & 0.207 & 0.275 & {$[0.75]$} & 0.007 & 0.005 & $1.36]$ \\
\hline \multirow[t]{2}{*}{ MLCF } & $\mathrm{D}(\mathrm{S})$ & -0.791 & 0.793 & [0.99] & 0.318 & 0.678 & $0.46]$ & -0.073 & 0.658 & [0.11] & 0.008 & 0.008 & [1.04] \\
\hline & $\mathrm{D}(\mathrm{F})$ & 0.923 & 0.710 & $\begin{array}{l}{[} \\
1.30]\end{array}$ & -0.044 & 0.607 & $\begin{array}{l}{[-} \\
0.07]\end{array}$ & 0.330 & 0.589 & [ 0.55$]$ & 0.005 & 0.007 & {$[0.74]$} \\
\hline \multirow[t]{2}{*}{ NBP } & $\mathrm{D}(\mathrm{S})$ & -1.657 & 0.707 & [2.34] & 0.775 & 0.474 & $\begin{array}{l}{[} \\
1.63]\end{array}$ & -0.690 & 0.483 & [1.42] & 0.001 & 0.008 & $\begin{array}{l}{[} \\
0.15]\end{array}$ \\
\hline & $\mathrm{D}(\mathrm{F})$ & -0.557 & 0.747 & {$[0.74]$} & 0.672 & 0.500 & $1.34]$ & -0.677 & 0.510 & [1.32] & 0.001 & 0.009 & $0.15]$ \\
\hline \multirow[t]{2}{*}{ NML } & $\mathrm{D}(\mathrm{S})$ & 0.180 & 0.187 & $\begin{array}{l}{[} \\
0.96]\end{array}$ & -0.074 & 0.185 & $\begin{array}{l}{[-} \\
0.39]\end{array}$ & 0.102 & 0.140 & [ 0.73$]$ & 0.001 & 0.008 & $\begin{array}{l}{[} \\
0.18]\end{array}$ \\
\hline & $\mathrm{D}(\mathrm{F})$ & 1.159 & 0.221 & $\begin{array}{l}{[} \\
5.24]\end{array}$ & -0.027 & 0.219 & $\begin{array}{l}{[-} \\
0.12]\end{array}$ & 0.137 & 0.166 & {$[0.82]$} & 0.002 & 0.010 & $\begin{array}{l}{[} \\
0.17]\end{array}$ \\
\hline
\end{tabular}




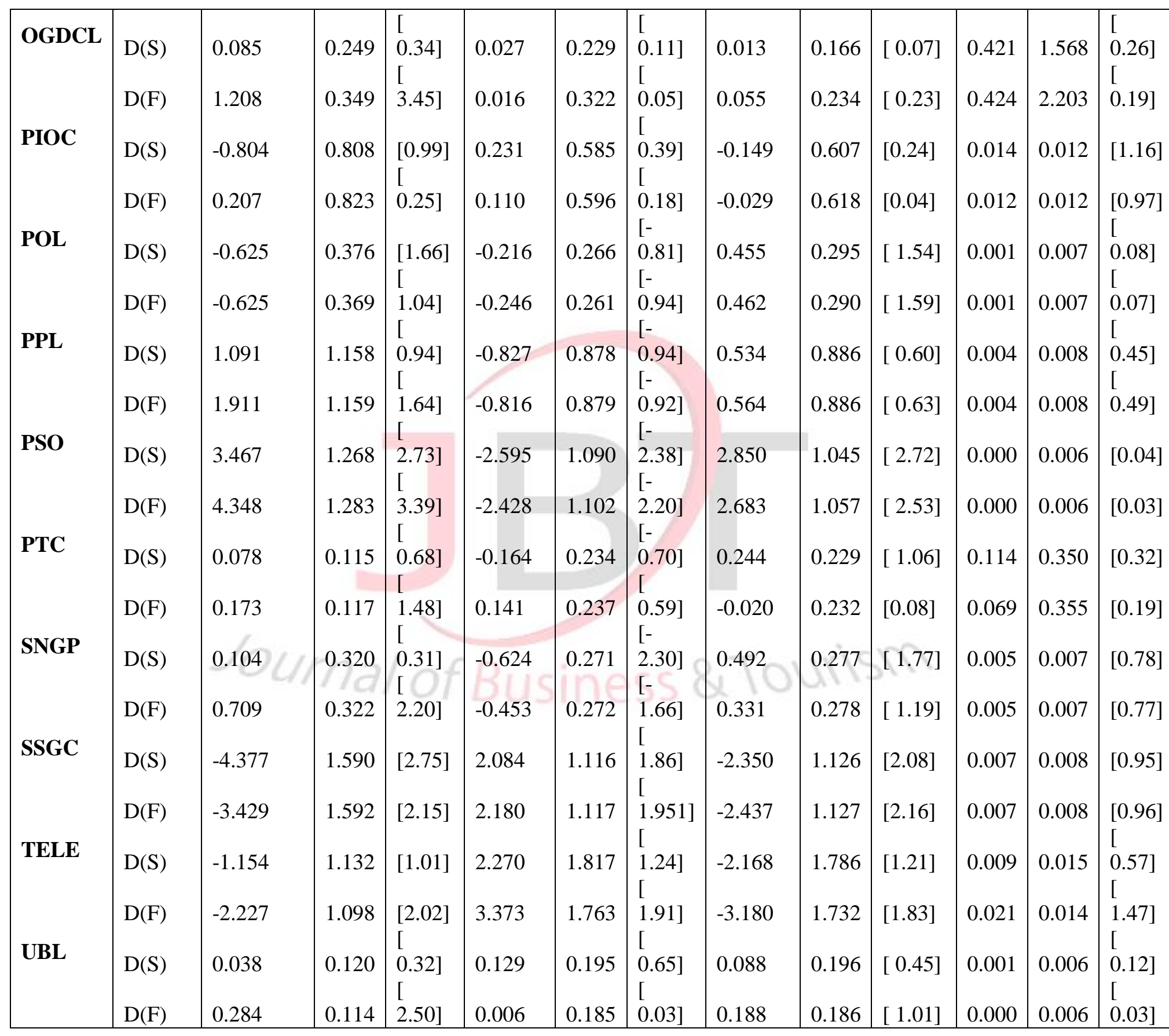

